\title{
Corporatism, fractionalization and state interventionism: the development of communication studies in Brazil
}

\author{
Afonso de Albuquerque • Camilla Quesada Tavares
}

Received: 23 September 2020 / Accepted: 16 October 2020 / Published online: 19 November 2020 (C) The Editors of the Journal 2020

\begin{abstract}
This article summarizes the development of education and research in Communication Studies in Brazil. It is argued that different factors contributed to the development of the particular features that Brazilian Communication Studies present nowadays. They include: the late development of Brazilian universities, in comparison to the western societies, but also to other Latin American countries; the relatively early development of Communication programs, beginning from the late 1940s, following the example of the United States; state interventionism in the universities' curricula, and the influence exerted by other non-academic social actors, such as journalists' unions. As the result of the influence of these factors, Communication Studies organized according to two entirely different logics: undergraduate studies focus on specialized professional fields (such as Journalism, Advertising, Public Relations, Cinema) and adopt a practical approach with respect to them; otherwise, graduate studies employ a much more general and academic approach focusing on Communication as a whole. The article also discusses the challenges faced by Communication Studies at present, resulting both from the changes in the media landscape and a hostile political scenario, associated with the rise of Jair Bolsonaro, an ultra-rightist politician who openly disdains science (and human sciences in particular).
\end{abstract}

Keywords Communication studies · Brazil · Corporatism · Graduate programs · State interventionism

Prof. Dr. A. de Albuquerque $(\bowtie)$. Prof. Dr. C. Q. Tavares

Fluminense Federal University, Professor Marcos Waldemar de Freitas Reis Street, s/n. Bloco A, 4o floor, São Domingos-Niterói, RJ, Brazil

E-Mail: afonsoalbuquerque@id.uff.br

Prof. Dr. C. Q. Tavares

E-Mail: camilla.tavares8@gmail.com 


\section{Introduction}

This article discusses the origins and the development of the field of Communication Studies in Brazil and the challenges it currently faces. In 1947, the Casper Libero College (Faculdade Cásper Líbero) founded the first undergraduate program in Journalism. Nowadays, there are almost 1800 undergraduate Communication Studies programs in Brazil. Why are there so many programs? How are they organized? Which forces influence the development and the configuration of the Communication Studies education and research in the country? In this article, we argue that Brazilian universities organize Communication Studies according to two entirely distinct logics — which are not only different, but essentially incompatible-in the undergraduate and the graduate levels.

Similar to other countries (cf. Josephi 2017; Löffelholz and Rothenberger 2011; Zelizer 2004), disputes between the academic and the professional approaches have been a key element of the constitution of Communication Studies in Brazil. Yet, these disputes assumed a peculiar feature in Brazil as a consequence of the combination of state interventionism in the curricula of undergraduate programs and pressures from professional (especially journalists') unions. Taken together, these factors have curbed the autonomy of the Communication faculties in defining their curricula.

Since 1962, Brazilian universities labeled Communication undergraduate programs as Comunicação Social (Social Communication). These followed the curricula established by the Ministry of Education (MEC). Typically, Communication programs organized as an umbrella of professional fields ("habilitações", in Brazilian Portuguese), such as Journalism, Advertising, Cinema, Public Relations, Radio and TV, and others. Originally, they had a generalist/humanistic bias, and students could obtain a polyvalent education. In the mid-1980s, this model became the subject of growing criticism from those defending a more professional-based approach. In fact, the following versions of the Communication curriculum systematically minimized the importance of the general/theoretical aspects of university education, in the benefit of technical skills associated with specific professions. In 2009, MEC ruled out the very possibility of Communication programs, and universities had to transform the former existing habilitações in independent programs on their own during the following years.

Graduate Communication programs adopt an entirely different structure. They usually focus on Communication and Media Studies in general and emphasize a humanistic/theoretical approach, rather than specific professional skills. Graduate studies adopted a two-step approach, as students must first conclude the mestrado (Master of Arts, or MoA) degree to apply to the doutorado (PhD) program. Since 1998, there is a new modality called mestrado professional (Professional Master of Arts). Not all programs offer PhD programs. The Coordination for the Improvement of Higher Education Personnel (CAPES, Coordenação de Aperfeiçoamento de Pessoal de Nivel Superior in Portuguese)—a federal government agency subordinated to the Ministry of Education-organizes the national structure of graduate studies and periodically evaluates them. Graduate programs enjoy much more autonomy in establishing their curricula than the undergraduate ones. 


\section{University education in Brazil: a historical background}

The development of Communication Studies in Brazil can be understood best through a postcolonial perspective. Two aspects deserve special attention here. On the one hand, universities developed late in Brazil, not only in comparison to the European nations, but also to the country's South American neighbors. Contrary to Spain, which created universities in their American colonies as early as in 1551 (Peru and Mexico) and 1613 (Argentina), Portugal avoided creating universities in its colonies, including Brazil. In a general manner, Brazilian elites used to study in Portuguese universities, especially at Coimbra University (cf. Carvalho 1996). Universities created the first medicine programs in 1808. In this year, the king of Portugal, João VI, moved to Rio de Janeiro with his court, fleeing the invasion of this country by Napoleon's troops (cf. Maxwell 2000). In consequence, Rio de Janeiro became the de facto capital of the Portuguese Empire until 1821, when the king returned to his native country. However, his son Pedro remained in Brazil, as Prince Regent. One year later, he declared the independence of Brazil. Pedro became Emperor of Brazil, known as Pedro the First. Pedro the Second succeeded his father and ruled until 1889, when a republican regime replaced the monarchy.

The persistence of the monarchic regime for several decades had a considerable impact on the identity of Brazilian elites. Different from the Spanish-speaking countries, which, following the example of the United States, emphasized their specific American character and became republics, Brazilian elites used to perceive their country as a European monarchy located in America. Even after the end of the monarchy, the privileged reference to Europe remained an essential trait of the Brazilian elites' identity. Indeed, republican activists blamed Brazil's Portuguese heritage as being the main reason for its perceived backwardness with respect to Europe and proposed to follow France as a model for the country instead. In this spirit, Rio de Janeiro-then the capital of Brazil—was subject to an ambitious reforming project, which aimed to make it a tropical version of Paris (cf. Carvalho 1990).

Studying abroad had become a defining element of the identity of the Latin American elites but in Brazil, the orientation towards Europe was so remarkable that it discouraged the creation of universities. Yet, a handful of Medicine, Law, and Engineering programs were created during the monarchic period. Because of this, they are sometimes described as "imperial professions" (Coelho 1999). The first Brazilian university was created in 1912 in Curitiba - the Universidade do Paraná, or University of Parana. Next came the University of Rio de Janeiro in 1920 and the University of São Paulo in 1934.

\subsection{The origins of communication studies in Brazil}

Communication programs developed relatively early in Brazil, in comparison to other countries: the Cásper Libero College created the first Journalism program in 1947; the Pontifícia Universidade Católica do Rio de Janeiro (Catholic University of Rio de Janeiro or PUC-RIO) founded the first Advertising program in 1951, and the Universidade Federal do Rio Grande do Sul (Rio Grande do Sul Federal 
University or UFRGS) established the first Public Relations program a year later. Throughout the 1950s, Brazilian universities created 14 Communication programs (7 in Journalism, 5 in Advertising, and 2 in Public Relations); in the 1960s, they established 18 programs ( 9 in Journalism, 5 in Advertising, 4 in Public Relations). Mainly federal public and confessional universities offered these programs. Between 1940 until the end of the 1960s, 37 new Communications programs were established: 18 in federal public universities and 19 in confessional-primarily Catholic_-ones.

The relatively premature development of Communication Studies in Brazil reflects the influence of a new foreign source of cultural influence: the United States. After World War II, the United States emerged as a superpower, the leader of the capitalistic world, in opposition to the Soviet Union. Brazil was an early target of the United States' soft power efforts. In fact, these efforts initiated during the period of the war. At that time, president Getúlio Vargas ruled Brazil ahead of a fascist type of political regime, known as Estado Novo, and was ambivalent about which side the country would take in the war. In its effort to convince Brazil to take its side, the United States recurred to the Office of the Coordinator of Inter-American Affairs (OCIAA), a public relations initiative directed by Nelson Rockfeller, under the auspices of the State Department, which promoted the ideal of good neighborhood between the United States and Latin America. This effort involved several initiatives, including massive advertising of US products in Brazilian media, the promotion of elements of the Brazilian culture (e.g., samba) in the United States, and the invitation of Brazilian artists and journalists to visit the United States (cf. Lins da Silva 1991; Tota 2009).

These efforts were considerably well succeeded and, by the 1950s, the United States replaced France as the core normative model for Brazilian journalists (cf. Jobim 1954). Indeed, in 1950 the Diário Carioca newspaper promoted a major reform, aiming to modernize Brazilian journalistic practices, based on the example of the US independent journalism model (cf. Lins da Silva 1991). In particular, the reference to the journalistic objectivity as their occupational model became a defining trait of the Brazilian journalists' professional identity, and an important element of their collective pride. According to a view that became dominant among the Brazilian journalists, the reform of Diário Carioca was the "first step to the modernity" of Brazilian journalism (cf. Lage 2002). Encouraged by the new sense of dignity that followed the reform, several journalists-especially those associated to journalists' unions - came to believe that establishing a university degree in journalism as a sine qua non condition to allow people to work as journalists would elevate its professional status by making it more similar to Medicine, Law, and Engineering (the "imperial professions"), which also have university degrees as prerequisites.

\subsection{The communication studies during the military regime (1964-1985)}

In 1969, the military junta, which was ahead of the Brazilian government, issued the Decree-Law 972. The decree established the requirement of a university degree in order to practice journalism (cf. Albuquerque and Da Silva 2009). The core intention behind the decree was providing the military rulers with the means to exert more ideological control over journalists. They worried about the notorious presence of 
a large number of communists working as journalists in Brazilian newspapers, even for those with a conservative editorial line. The proprietor of $O$ Globo, a conservative newspaper supporting the military regime, used to refer to them as "my communists". This happened due to different reasons. To begin with, communists had a good reputation as skilled professionals and they had an important role in the Brazilian journalism modernization process. More importantly, the proprietors of conservative newspapers considered communists to be more disciplined than other journalists. After all, they knew that their presence in these papers' newsrooms came with a price: they should never challenge the papers' editorial line; rather, communists worked as a source of discipline in the newsrooms (at least not in an explicit manner). In exchange, the proprietors allowed them to exert their job with a considerable degree of autonomy, including the opportunity to hire fellow communists to work with them. Moreover, they could count on some degree of political protection from their bosses, which proved to be particularly useful during the dictatorial period.

However, from the military rulers' perspective, this arrangement looked suspicious. In their view, communism was an "exotic ideology", which presented a serious risk to the country's national security. By establishing the university degree as a prerequisite for the professional exercise of journalism, they expected to rise a technical barrier against the employment of communists by the newspapers. This hope relates to significant changes happening in the Brazilian university system at that time, which resulted from a series of agreements between the Brazilian Ministry of Education and the United States Agency for International Development (Usaid) in the mid-1960s (cf. Motta 2014). In the view of the military rulers, this could allow Brazilian students' introduction to an "Americanized" approach to journalism, which, they hoped, would provide an antidote to the communist influence among Brazilian journalists.

The relations between journalists' unions and military rulers have been often tense, and sometimes openly hostile. In spite of this, journalists' unions welcomed enthusiastically the requirement of a journalism degree, arguing that this was in line with their historical demand. In fact, this topic became the subject of an intense debate after the fall of the military regime in the mid-1980s. Then, the elaboration of a new, democratic constitution-in substitution to the authoritarian piece inherited from the previous regime-was debated and some politicians questioned the exigence established by the Decree-Law 972. They based their queries on the argument that this demand went against the constitutional principle of freedom of expression. In the following decades, preserving the professional monopoly for university degree holders remained the most important unifying cause for Brazilian journalists' unions. It was only in 2009 that a judicial decision excluded this exigence.

\subsection{Communication studies after the democratization process}

Communication programs experienced a huge expansion in Brazil after the return to democracy. Table 1 presents the evolution of the number of programs in Journalism, Advertising, and Public Relations. The data show a remarkable expansion in Journalism and Advertising, although not so intense in Public Relations. Indeed, in the 1990s, the amount of Journalism programs almost tripled, and in Advertising al- 
Table 1 Creation of programs according to the decades. (Ministry of Education, organized by the authors 2020)

\begin{tabular}{llll}
\hline Decade & \multicolumn{2}{l}{ Number of Programs } & \\
& Journalism & Advertising & Public Relations \\
\hline 1970 & 42 & 10 & 6 \\
1980 & 63 & 39 & 26 \\
1990 & 76 & 41 & 34 \\
2000 & 201 & 152 & 53 \\
2010 & 445 & 382 & 57 \\
\hline
\end{tabular}

most quadrupled. In the 2000s, they increased twofold in comparison to the previous decade. During the governments of Presidents Luiz Inácio Lula da Silva (2003-2010) and Dilma Rousseff (2011-2016), both belonging to the Workers' Party (Partido dos Trabalhadores, hereafter PT), the Brazilian university system experienced a major expansion, as a consequence of the Program to Support Initiatives of Restructuration and Expansion of Federal Universities $(R E U N I)$. It promoted the creation of fourteen new federal universities and more than a hundred new university campuses. The number of cities with federal university campuses increased from 114 to 237 in eight years. From 2003 to 2016, the number of students in federal universities more than doubled, from 540,000 to 1,180,000. Lula's and Rousseff's governments also increased investments in higher education and adopted affirmative-action policies, aiming to open federal universities to more non-white and poorer students, who had been historically excluded from them.

The increase in the number of programs went hand in hand with a change in the profile of the educational institutions offering them. Commercial educational institutions became the bulk of the system. Indeed, despite the fact that the number of programs offered by public and confessional institutions increased between 1960 and 2010 from 18 to 131 and from 19 to 518, respectively, the percentage of programs offered by them decreased from $48 \%$ to $7.3 \%$ in public institutions and from $52 \%$ to $29 \%$ in confessional institutions during the same period. The consequences of this change in the profile of undergraduate Communication education will be further discussed.

The period following the end of the military dictatorship was also characterized by intense debates about Communication curricula, especially with respect to Journalism. Given the importance the journalists' unions attributed to the university degree as a core element of the journalists' professional identity, it is no surprise that they have acknowledged the curriculum as a topic of prime interest. In particular, departing from the 1980s, they have positioned themselves against a generic Communication Studies curriculum.

In 2009, the National Council of Education initiated some debates to modify the nomenclature of the undergraduate programs, seeking to make them more specific. The objective was to end the habilitações, as it happened in Communication (cf. Kunsch and Gobbi 2016). This was done by establishing the National Curriculum Guidelines, a technical report developed by a committee formed by professors in each area, who proposed a new minimum curriculum for undergraduate education. In the area of Communication, Cinema and Audiovisual were pioneer, creating specific curricular guidelines in 2006, well before the national movement by MEC. In 2013, 
the new guidelines for the Journalism and Public Relations were published. The Advertising guidelines are still in discussion and the proposal will be presented by the commission soon.

After the implementation of the new guidelines, the "habilitações" model vanished from Communication undergraduate education. This process led the way to more specific undergraduate bachelor programs. In practice, disciplines have become more specific, discussing themes and concepts related to each area in question. According to their defenders, the initiatives recommending to ameliorate the undergraduate education "correspond to the views of unions and academic institutions, which defend a high-quality journalism teaching, and obtain an additional legitimacy from explicit declarations made by journalism organizations, which assure that they will remain hiring professionally competent people with a journalism degree, even if this is no more a legal obligation" (Diretrizes Curriculares Nacionais 2013).

On the one hand, there is a defense of the curricular guidelines because they generally guide the programs' structure and require a more or less equal training in different universities, on the other hand they hamper the curricula. Bachelor programs have little autonomy to elaborate and offer disciplines, since they need to be associated with the minimum curriculum. If this is a characteristic that tends to predominate in programs in Communication at the undergraduate level, the same is not observed at the graduate level. Master's and doctoral programs experience greater autonomy to conceive the programs, as we will discuss next.

\section{Graduate programs in communication studies}

Graduate programs in Communication exist in Brazil since the 1970s: the São Paulo Pontifical Catholic University (Pontifícia Universidade Católica de São Paulo or PUC-SP) created the first one in 1970, focusing on the interplay between Communication, Literature, and Semiotics. In the same decade, four other programs were created, by the University of São Paulo (Universidade de São Paulo or USP) and the Rio de Janeiro Federal University (Universidade Federal do Rio de Janeiro or UFRJ), both in 1972; the University of Brasilia (Universidade de Brasília or UnB) and the Methodist University of São Paulo (Universidade Metodista de São Paulo or UMESP), in 1978. Although structured in different manners, all these programs adopted a broad, critical approach to Communication Studies instead of a professional-oriented one. In 1986, the University of Campinas (Universidade de Campinas or Unicamp) created another program, also located in the state of São Paulo. Its main research focus lay on Audiovisual and the interface between Communication and Arts. Therefore, in the two first decades, Brazilian graduate programs were geographically concentrated in only two states-São Paulo and Rio de Janeiro-and the Federal District, where Brasília, the capital of Brazil is located.

The number of graduate programs in Communication grew considerably in the following decades, achieving a more balanced regional distribution. In the 1990s, nine programs were created: three in Rio Grande do Sul and one in Bahia, Minas Gerais, Rio de Janeiro, São Paulo, Pernambuco, and Paraná. In the 2000s, 16 more programs were established: five in São Paulo, two in Rio de Janeiro and Minas 
Gerais, and one in Rio Grande do Sul, Goiás, the Federal District, Paraná, Paraíba, and Rio Grande do Norte. At the end of the 2010s, there are Communication programs in all but three states (Acre, Amazonas, and Rondônia). Still, most programs are concentrated in the southeastern region (13 in São Paulo, 7 in Rio de Janeiro, 5 in Minas Gerais, 1 in Espírito Santo), as well as in the Southern states (5 in Rio Grande do Sul, 4 in Paraná, 1 in Santa Catarina).

Contrary to what happened to the undergraduate programs, public-owned universities are the bulk of the Communication graduate programs. Roughly three quarters of Communication programs are affiliated to public universities: 34 to federal universities, seven to state universities, and one to a municipal university. Private-owned universities are responsible for 15 programs, from which confessional institutions have nine affiliated programs ( 8 Catholic and 1 Methodist) and six other privateowned ones (5 of them located in São Paulo state and 1 in Paraná). At the present, there are 57 Communication programs in Brazil: 32 offer Ph.D. and MoA programs, 16 offer only academic MoA, and nine offer professional MoA programs.

Graduate programs are periodically evaluated by CAPES, which attributes them with grades from 1 (minimum) to 7 (maximum). Programs receiving a grade 1 or 2 must cease their activities. Only programs earning at least grade 4 may run $\mathrm{PhD}$ programs. At present, UFRJ has the only program earning a grade 7 . Three other programs, offered by the Fluminense Federal University (Universidade Federal Fluminense or UFF), the Minas Gerais Federal University (Universidade Federal de Minas Gerais or UFMG), and the Vale do Rio dos Sinos University (Universidade do Vale do Rio dos Sinos or Unisinos, located in Rio Grande do Sul) earn a grade 6. Eight programs earn a grade 5: Advertising and Marketing Superior School (Escola Superior de Propaganda e Marketing or ESPM), Rio Grande do Sul Pontifical Catholic University (Pontifícia Universidade Católica do Rio Grande do Sul or PUC$\mathrm{RS}$ ), State University of Rio de Janeiro (Universidade do Estado do Rio de Janeiro or UERJ), Bahia Federal University (Universidade Federal da Bahia or UFBA), Pernambuco Federal University (Universidade Federal de Pernambuco or UFPE), Santa Maria Federal University (Universidade Federal de Santa Maria or UFSM), Rio Grande do Sul Federal University (Universidade Federal do Rio Grande do Sul or UFRGS), and Tuiuti University of Paraná (Universidade Tuiuti do Paraná or UTP).

With the exception of UFRJ, no other first-generation program is on the list of the best-ranked programs in Communication. Second-generation programs, founded in the 1990s or early 2000s, provide the bulk of this list because, in the 1990s, Communication graduate studies experienced a major change, associated to the creation of Compós (Communication Graduate Programs' National Association or Associação Nacional dos Programas de Pós-Graduação em Comunicação) in 1991. Until then, the level of exchange between Brazilian Communication graduate programs was almost nonexistent, both with respect to intellectual approaches and faculty-in some cases, as in USP and UFRJ, more than $90 \%$ of the faculty members graduated in the same program they worked at. By organizing annual meetings and providing a national forum for the debate about graduate studies and research, Compós played a strategic role in the consolidation of a shared academic culture among Brazilian graduate programs. 


\subsection{The evolution of communication research in Brazil}

Similar to other Latin American countries, Communication research has a long history in Brazil. In fact, the creation of the Centro Internacional de Estudos Superiores de Comunicacción para América Latina (International Center of High Studies for the Latin America or CIESPAL) in 1959, under the auspices of UNESCO (cf. Aragão 2018), and the Asociación Latinoamericana de Investigadores de la Comunicación (Latin American Communication Researchers Association or ALAIC) in 1978, provided a solid institutional basis for intellectual exchanges between Latin American researchers sooner than the experience in other regions of the world. The linguistic homogeneity existing in the region played a key role in facilitating communication between the researchers: at present, more than 600 million people speak Spanish or Portuguese-both Romance languages-in the region. During the 1960s to 1980s, Latin America became a stronghold for the critical perspective in Communication Studies, in opposition to the administrative approach prevailing in the United States. This happened for two main reasons. On the one hand, the electronic mass media became prematurely more central in Latin America societies-which have been described as television-centered (cf. Hallin and Papathanassopoulos 2002)—than in most of European societies.

In some cases, as in Brazil, Mexico, and Venezuela, radio and television adopted a commercial model borrowed from the United States. On the other hand, some Latin American intellectuals often perceived the US influence, both in their countries' media and academic fields, as having an imperialistic nature. In the words of Beltran (1976, p. 109): "Latin American communication research has been, and is yet, considerably dominated by alien conceptual models, stemming chiefly from the United States of America."

Among the Brazilian intellectuals active at that time, probably none was more influential than Paulo Freire, an education philosopher who was the most important leader of the critical pedagogy school. According to Freire (1970), the main goal of education was not to transmit contents to passive students-a view that he referred to as a "banking conception" of education-but stimulating the oppressed to raise critical consciousness about their situation and to become active promoters of their liberation process. Accordingly, Brazilian (and Latin American) intellectuals perceived their countries' "Americanized" mass media—and the ideology of developmentalism (cf. Bodenheimer 1970) promoted by them-as an instrument of oppression and alienation, in the service of US cultural imperialism. The idea that mass media should serve as an instrument for the promotion of cultural diversity instead of merely seeing to commercial interests was one of the sources of the document "Many Voices, One World", also known as the "MacBride Report", which was originally published by UNESCO in 1980 (International Commission for the Study of Communication Problems 2004).

At present, Latin America lost much of the international influence it had in the past (cf. Enghel and Becerra 2018; Ganter and Ortega 2019). Why did this happen? It is noteworthy that the visibility of Latin America occurred hand in hand with the internationalization process of Communication research, which gained impulse in the 1990s to 2000s. According to a certain view, Latin American scholars themselves 
are to blame for the decline of their international visibility, given their failure in accepting that the rules changed and English became the language of scientific discussions at an international level and their refusal to conduct empirical research (cf. Saucedo Añez 2019). This view is simplistic, however, as it takes the rise of English as the language of international science as a fact of nature, rather than history. The Anglophone process of academic globalization is inseparable from the neoliberal globalization process, which has been led by the United States, and, secondarily, by the United Kingdom. The Anglophone globalization process not only defined English as the universal language of science, but built an institutional structure that defines what is relevant science and what is not: anglophone-dominated ranking institutions rank Anglophone educational institutions and Anglophone academic journals as being "world-class", and, in consequence, attribute a second-class status to others.

This proved to be a disaster for the Latin American scholarship, as it deprived it of its previous international status. An example of how this happened lies in the universe of the members of editorial boards of journals ranked by Clarivate's Journal of Citation Reports: 2798 of these members work in US institutions, 398 in UK institutions, and 50 in Latin American and Caribbean institutions. The University of Texas-at which there is a center of Latin American studies-has almost twice the amount (92) of members than the entire Latin American/Caribe region in JCR's system (cf. Albuquerque et al. 2020). This has obvious political consequences, as it provides US-based scholars with the power to define what Latin American is in the "world-class" circuit.

The impact of the Americanization of Brazilian Communication graduate programs has been very modest, at least with regard to their faculties' education. For instance, in every best-ranked (grade 7) Economy program, more than half of the faculty earned their PhDs in the United States (cf. Albuquerque 2018). This trend is in line with the observation, made by Dezalay and Garth (2002), that the access to foreign universities (at present, especially those located in the United States) is an important distinctive element that Latin American elites use as means to legitimate themselves. In Communication programs, the picture is considerably different. From the 220 professors working in the twelve best-ranked (grades 7 to 5) Communication programs, roughly $15 \%$ of them (34) obtained their PhDs abroad. Only three of them graduated in the United States, in comparison to 16 in France. Still more important, foreign $\mathrm{PhD}$ titles have diminished in the recent years, as the number of programs increased in Brazil.

\section{The state of art of current Brazilian communication research}

At present, research on Communication in Brazil is considerably rich and diversified. To begin with, the country has many scientific organizations. Some of them adopt a general focus on Communication, as the aforementioned Compós and Intercom (which is older than Compós, founded in 1977). Others adopt a more specific approach, by focusing on specific topics as Journalism (SBPJor), New Media 
(ABCiber), Cinema Studies (Socine), and Political Communication (Compolítica), among many others.

Brazil also counts with a considerable number of scientific journals in Communication. In contrast to what happened in other countries-especially within the Anglophone "prestige" journals_all well-reputed Brazilian journals are open access and do not require submission or publication fees (this rule applies to other Latin American journals, too). This characteristic works as an important factor for democratizing access to scientific knowledge, as, in the Global South, journals' paywalls provide an important obstacle hampering access to scientific articles. As it happens to the graduate programs, journals are also ranked by CAPES. Well-ranked Communication journals are often affiliated either to scientific organizations or to graduate programs. E-Compós (affiliated to Compós), Intercom-Revista Brasileira de Ciências da Comunicação (affiliated to Intercom) and Brazilian Journalism Research (affiliated to SBPJor) provide examples of the first case. Examples of wellranked journals affiliated to graduate programs are Matrizes (USP), Galáxia (PUCSP), Revista Famecos (PUC-RS), and Contracampo (UFF).

Brazilian Communication research has explored a variegated chart of themes. Among them, Political Communication is the most consolidated field and the most internationalized (at least from an Anglophone point of view). It has been the subject of systematic research since the late 1980s and especially after Fernando Collor de Mello's rise to the presidency in 1989: a relatively unknown politician, running for a coalition of small parties, he was able to defeat much more experienced politicians thanks to this thoughtful use of mass media, television in particular, by exploiting the image of a brave young warrior fighting against corruption. His spectacular fall, in 1992, after numerous corruption accusations led to an extremely mediatized process which made his case even more appealing for Brazilian researchers.

The nature of the Brazil's free-time model of political advertising and the role of the news media as political agents became topics of great interest for researchers since then. In the mid-1990s, questions related to the potential of the media to serve as a basis for an enriched public sphere-under the inspiration of the work of Jürgen Habermas - gained growing attention from Brazilian scholars. During the 2000s, Brazilian researchers' focus progressively moved to digital media. Initially, this movement was inspired by an optimistic belief about the potential of these media to ameliorate the quality of democracy, either by promoting more direct participation of common citizens in politics or, complementarily, make political institutions (government, political parties ...) more accountable to the citizens. Recently, this optimism ceded ground to a more cautious, even pessimistic attitude, as Brazilian democracy has shown clear signals of crisis.

A second consolidated research field refers to the studies on media reception. Brazilian Reception Studies-which explore the role that audiences play in the communication process - are more internationalized, too, but differently than Political Communication, they circulate preferentially in a Latin American rather than in an Anglophone circuit. More than any other field of Brazilian communication research, Reception Studies keep alive the legacy of the Latin American critical school. The trajectory of critical reception studies in Brazil can be traced to the late 1970s, when the program Critical Lectures in Communication was created by an 
organization linked to the Catholic Church, based on the ideas of Paulo Freire (cf. Jacks and Schmitz 2019). The Brazilian tradition of Reception Studies developed in close connection with the Latin American Cultural Studies tradition, which has Jesús Martin-Barbero and Nestor Garcia-Canclini as its main exponents (cf. Escosteguy 2001).

The much more recent field of New Media Studies focuses on digital media's impact on social practices and culture. Different from what happened elsewhere, the development of this field in Brazil reflects a French rather than Anglophone influence. The work of French philosopher Pierre Lévy (and secondarily Bruno Latour) have been particularly influential. In fact, Brazilian researchers adopted the name Cibercultura (Cyberculture) to describe their research area (cf. Recuero 2015) after the title of Lévy's book (it is worth to note that Lévy's popularity is essentially a Brazilian phenomenon, with no parallel in any other country, including France). As digital media become more central in the current mediascape, the use of the expression "new media" to describe it loses its reason of being and, at the same time, the field tends to break off in other, more specialized subfields that become progressively more autonomous to each other.

The nature of the insertion of Journalism Studies as a field in Communication research has been the subject of controversies all over the world (Löffelholz and Rothenberger 2011; Zelizer 2004). Yet, the manner in which Brazilian mainstream researchers have dealt with this issue has some notable peculiarities, which result from the influence of the journalists' corporate logic on the academic agenda. Machado (2005), for instance, traces a fundamental distinction between journalism studies - which derivate from an outside view regarding the field—and journalism theories, made by journalists, reflecting about their professional practice. He presents Michael Schudson, Gaye Tuchman, Teun Van Dijk, and Berry Gunther as examples of authors who examine journalism from afar and therefore fail to consider "the ontological and deontological raison d'être of objectivity" and other journalistic values and practices (Machado 2005, p. 16). In this view, Journalism research is first a branch of the journalistic profession, and only then an academic area, and should be carried on by professional journalists - who, as seen before, are defined by the possession of a bachelor's degree in journalism rather than working in journalist organizations. This view discourages critical approaches to journalism, which are considered to be "external to the field".

The last subfield of Brazilian communication research deserving special attention is Cinema Studies. Similar to Journalism, research in Cinema Studies opposes the logic of a specialized professional field to the general logic of "Communication Theories". Yet, different from what happens to Journalism, Cinema Studies research focuses on a "prestige", "artistic" subject, rather than on the technical aspects of everyday practice. 


\section{Communication studies: current challenges and prospects for the future}

Currently, Communication Studies face important challenges in Brazil. Some relate to the structure of education and research both in the undergraduate and graduate programs and its adequacy to face a growingly complex informational environment. Others have to do with politics: Brazilian universities-especially the publicowned ones-face a grim situation, as the current president Jair Bolsonaro maintains a hostile attitude towards them-whom he blames for allegedly promoting "Cultural Marxism", a catch-all category that includes in the same pot communists, social progressists, and even global businesspeople as, for instance, George Soros-and science in general. Yet, despite the presently ongoing difficulties, the prospects for the development of Communication Studies in Brazil are not necessarily somber, as, in a changing world, universities play a crucial role in the diagnosis of emerging problems and the proposal of adequate solutions to deal with them.

\subsection{Structural challenges for communication studies}

Recent changes in the media landscape present a serious challenge to Brazil's Communication Studies model. As seen previously, undergraduate and graduate Communication programs follow entirely different models: on the one hand, graduate programs adopt a generalist and theoretical approach to Communication; on the other hand, undergraduate programs became increasingly fractioned, in part due to the influence of corporate interests associated to established professions, especially journalism.

Moreover, contrary to what happened to graduate programs - in which faculties enjoy considerable autonomy in establishing their programs' curricula-the state subjects the undergraduate formation to a considerable degree of interventionism, which results in a strong ossification of their curricula. In fact, the structure of Communication undergraduate programs still reflects the analogic model of discrete media and is inappropriate in dealing with the wide range of problems associated with the rise of the digital (and social) media. Due to this fractionalized logic, Brazilian undergraduate programs prepare their students for professional markets-as, for instance, newspapers-which experience a severe crisis, as job opportunities decline everywhere. The ossified nature of these programs' curricula aggravates the problem, as it makes it difficult for them to adapt to new circumstances, such as the social (and professional) consequences that result from the emergence of new communication technologies, for instance.

The disdain with respect to theory still prevailing in the Brazilian undergraduate programs - such as Journalism and Public Relations-contributes to magnify this problem. The very nature of media is experiencing deep changes at a fast pace, and still more important, traditional media outlets face a major legitimacy crisis. Thus, Communication theory is ever more needed. The very idea of a "technical" approach to Communication studies looks naïve in a time when terms as "post-truth era" and "fake news" become part of the everyday vocabulary and growing anxiety emerges about the impact of social media platforms and disinformation campaigns. 
To be sure, all these issues have been topics of study and research in Brazilian graduate programs, but the ossified structure of undergraduate programs minimizes their impact on students' education. Recently, a new model of undergraduate program-Media Studies-committed to a more holistic view of Communication and a more flexible curriculum more akin to Communication graduate programs emerged in Brazil. These characteristics allow the Media Studies curriculum to adapt much more easily than the traditional Communication programs to changes in the mediascape. However, the prevalence of corporate logic has inhibited the development of Media Studies in Brazil. Presently, there are only two such programs in the country: UFF founded the first one in 2005, while PUC-RIO created theirs in 2020.

\subsection{A hostile political scenario}

Another set of challenges Communication Studies face in Brazil have to do with the country's current political scenario. The rise of Jair Bolsonaro-an ultra-right politician who openly disdains science (and human sciences in particular) - to Brazil's presidency presents somber perspectives for the development of Communication education and research in the country. We highlight two of these challenges: the ideological harassment against intellectuals and universities' faculty members; and anti-university policies associated with the far-right's anti-multiculturalism and antiscience populism.

During the Bolsonaro era, there have been plenty of cases of ideological harassment against intellectuals and faculty members. Yet, hate campaigns against these individuals began years before, during Dilma Rousseff's government. In a great measure, they were not carried out by far-right extremists, but by agents belonging to the Judiciary, Prosecutors' Offices, the Federal Police, and no less important, mainstream media outlets, as part of an effort to remove Rousseff from her office by any means. The start of the Lava Jato Operation, led by the Federal Judge Sergio Moro, was decisive in this regard, as it systematically associated Lula (and leftist politicians in general) to corruption and described PT as a "criminal organization"- an accusation that was exhaustively repeated by the mainstream media (cf. Albuquerque 2019; Albuquerque and Gagliardi 2020, in print). As a consequence of Lava Jato, Lula was condemned for corruption acts-based on fragile evidence (cf. Meyer 2018) —and forbidden to run for the presidency in 2018, clearing way for Bolsonaro's victory; subsequently, the president nominated Moro for the Ministry of Justice (cf. Albuquerque and Gagliardi 2020, in print). Recently, numerous accusations of partiality have been raised against Moro and other members of the Lava Jato prosecutorial team (cf. Intercept Brasil 2019).

Because federal universities were considered to be an environment particularly favorable to the PT governments, they became the target of numerous attacks, which remained after Dilma Rousseff's impeachment. In 2017, judicial investigations against Jaime Arturo Ramirez and Luis Carlos Cancellier, respectively the rectors of UFMG and UFSC (Universidade Federal de Santa Catarina or Santa Catarina Federal University) started under accusations of corruption. Feeling depressed as a consequence of the accusations, Cancellier committed suicide. Other initiatives, as the movement Escola Sem Partido (NonPartisan School), were pro- 
moted, aiming to intimidate schoolteachers and university professors who, allegedly, were indoctrinating students. On December 6, 2017, the newspaper Gazeta do Povo launched the Indoctrination Monitor with the purpose of positioning itself as a vehicle to denounce teachers and professors promoting ideological agendas. Yet, Gazeta canceled the initiative a few days later in face of the backlash it had among its readers.

Despite the fact that Bolsonaro and his political allies use incendiary rhetoric against the influence of "leftists" and "communists" - in 2018, during the electoral campaign, he even suggested to shoot down PT members ("fuzilar a petralhada", in Portuguese)_-in a practical level, the impact of their attacks has been quite limited. This happens because Bolsonaro's worldviews are so extremist that they use the label "communists" to describe a variegated group of agents, such as PT and its political allies, the Globo TV Network, the Folha de S. Paulo newspaper and other mainstream media as well as globalist businessmen like George Soros. Under Bolsonaro, the political forces that in the past stood united against the PT governments became political rivals and now turn their destructive energy against each other.

The most serious challenge that Bolsonaro presents to Communication Studies (and Brazilian universities as a whole) has to do with another factor: the strong antiintellectual attitude that defines the relationship of his government (and political supporters) with respect to science, in general, and the universities, in particular (cf. Oliveira et al. 2020). This characteristic has been evidenced, on an everyday basis, in his management of the COVID-19 pandemic in Brazil, as he minimized its importance calling it "a little flu", opposed social distance measures and the obligation of wearing a mask and cast doubts about vaccination, preferring, instead, to promote alternative treatments, based on the use of hydroxychloroquine, for instance.

Bolsonaro's anti-intellectualism is not an anecdotal trait of his personality; rather, it is a consistent political attitude, accordant to a populist worldview (cf. Merkley 2020) and far-right activism (cf. Forchtner et al. 2018). Mede and Schäfer (2020, p. 484) refer to its specific arrangement as science-related populism, which they define in terms of a moral antagonism between "an (allegedly) virtuous ordinary people and an (allegedly) unvirtuous academic elite". Concretely, this antagonism has resulted in severe cuts in the research budget (cf. Escobar 2019). Bolsonaro's government members and political allies have been especially distasteful to human sciences. Paulo Freire, in particular, became a preferred target of Bolsonaristas, who accuse him to be the inspiring source of a broad process of communist brainwashing in Brazilian schools (cf. Gomes and Muller 2019). Naturally, the politically motivated attacks against Freire put in jeopardy his legacy with respect to the critical studies on Communication.

\section{Prospects for the future}

Communication Studies face a serious crisis in Brazil, but there is no reason for scholars to suppose that this is a terminal one. As they disturb entrenched beliefs, crises foster a sense of insecurity in all sectors of society-university included. Yet, 
crises must be faced, and the very step to be taken in this direction is to search for explanations about what is happening and why it happens and this is the very reason universities exist. The current Brazilian crisis is both political and social and one of its key factors has to do with the changing role of media in society. On the one hand, the Brazilian mainstream media has been sometimes blamed for promoting political polarization and, by doing this, contributing to undermine democracy (cf. Albuquerque 2019; Albuquerque and Gagliardi 2020, in print). On the other hand, the rise of social media has been associated with the massive distribution of disinformation, which arguably made Bolsonaro's path to the Brazilian presidency easier. In this scenario, the Brazilian longstanding tradition of critical research may be a valuable intellectual resource.

Nevertheless, we note that at present, Brazil experiences, in a more extreme form, a crisis that is happening on a global scale: the decline of the authority of the mainstream media and the institutions traditionally associated to democracy, anxieties related to the role of social media as political and social agents and the rise of anti-institutional forces, hostile to democracy, occur everywhere, although in different degrees.

These circumstances relate to another important global trend, which may result in the end of the US-centered unipolar world. As seen above, the restructuration of the academic around the United States, starting in the 1990s, established English as the global language of science and provided the Anglophone societies with an important competitive advantage in comparison to others: anglophone (mainly the US) ranking institutions define the US (then other Anglophone western societies, then other western societies) universities and journals as the unquestionable standards defining what the "world-class" academic circuit is. One of the consequences of the triumph of this logic was the downgrade of the status of Latin American (and Brazilian) Communication research (cf. Albuquerque et al. 2020). Yet, Latin American researchers managed to sustain a rich regional academic exchange in Communication Studies based on open access journals. This experience may provide useful clues in a time when demands for a "deep internationalization", which goes beyond the Anglophonic academic monoculture, become common (cf. Badr et al. 2020).

\section{References}

Albuquerque, A. (2019). Protecting democracy or conspiring against it? Media and politics in Latin America: a glimpse from Brazil. Journalism, 20, 906-923.

Albuquerque, A., \& Da Silva, M. (2009). Skilled, loyal and disciplined: communist journalists and the adaptation of the American model of 'independent journalism' in Brazil. The International Journal of Press/Politics, 14, 376-395.

Albuquerque, A., \& Gagliardi, J. (2020). Democracy as corruption: the news media and the debunking of democracy in Brazil. In X. Orchard, S. García, J. Brambila \& J. Lugo-Ocando (Eds.), Media \& governance in Latin America: towards a plurality of voices. New York: Peter Lang.

Albuquerque, A., Oliveira, T. M., Santos Junior, M. A., \& Albuquerque, S. O. F. (2020). Structural limits to the de-westernization of the communication field: the editorial board in Clarivate's JCR System. Communication, Culture \& Critique, 13, 185-203.

Albuquerque, S. (2018). Formação e reprodução de conhecimento científico: uma análise da formação professores de pós-graduação em economia no Brasil. Paper presented at the 42nd Anpocs Annual Conference, Caxambu, Minas Gerais. Formation and reproduction of scientific knowledge: an analysis of the formation of post-graduate teachers in economics in Brazil 
Aragão, I. (2018). Primeira década do Ciespal: fundação e indicações de investigação [First decade of Ciespal: foundation and research indications]. In G. M. Ferreira \& C. Peruzzo (Eds.), Comunicação na América Latina: da metapesquisa aos estudos midiáticos [Communication in Latin America: from meta-research to media studies] (pp. 147-174). São Paulo: Intercom.

Badr, H., et al. (2020). Kosmopolitische Kommunikationswissenschaft: Plädoyer für eine ,tiefe Internationalisierung" des Fachs in Deutschland [Cosmopolitan communication studies: A plea for "deep internationalization" of the discipline in Germany]. Publizistik, 65, 295-303.

Beltran, L. R. (1976). Alien promises, objects, and methods in Latin American communication research. Communication Research, 3(2), 107-134.

Bodenheimer, S.J. (1970). The ideology of developmentalism: American political science's paradigmsurrogate for Latin American Studies. Berkeley Journal of Sociology, , 15, 95-137.

Carvalho, J. M. (1990). A formação das almas: o imaginário da República no Brasil [The formation of souls: the imaginary of the Republic in Brazil]. São Paulo: Companhia das Letras.

Carvalho, J. M. (1996). A construção da ordem: a elite política imperial; Teatro de Sombras: a política imperial [The construction of the order: the imperial political elite; Shadow Theater: the imperial policy]. (2nd edn.). Rio de Janeiro: Editora UFRJ/Relume Dumará.

Coelho, E.C. (1999). As profissões imperiais: medicina, engenharia e advocacia no Rio de Janeiro, 1822-1930 [The imperial professions: medicine, engineering and advocacy in Rio de Janeiro, 1822-1930]. Rio de Janeiro: Record.

Dezalay, Y., \& Garth, B. (2002). The internationalization of palace wars: lawyers, economists, and the contest to transform Latin American states. Chicago: University of Chicago Press.

Diretrizes Curriculares Nacionais para o Curso de Jornalismo (2013). Relatório da Comissão de Especialistas instituída pelo Ministério da Educação [Report of the committee of experts set up by the ministry of education]. http://portal.mec.gov.br/dmdocuments/documento_final_cursos_jornalismo. pdf. Last access: 10 November 2020

Enghel, F., \& Becerra, M. (2018). Here and there: (re)situating Latin America in international communication theory. Communication Theory, 28, 111-130.

Escobar, H. (2019). Brazilian scientists lament 'freeze' on research budget. Science, 364(6436), 111.

Escosteguy, A.C. (2001). Culture studies: a latin American narrative. Media, Culture \& Society, 23, 861-873.

Forchtner, B., Kroneder, A., \& Wetzel, D. (2018). Being skeptical? Exploring far-right climate-change communication in Germany. Environmental Communication, 12, 589-604.

Freire, P. (1970). Pedagogia do oprimido [Pedagogy of the oppressed]. Rio de Janeiro: Paz e Terra.

Ganter, S. A., \& Ortega, F. (2019). The invisibility of Latin American scholarship in European media and communication studies: challenges and opportunities of de-westernization and academic cosmopolitanism. International Journal of Communication, 13, 68-91.

Gomes, W. M., \& Muller, A. J. (2019). Paulo Freire: do (re)exílio brasileiro às catedras norte-americanas [Paulo Freire: from the Brazilian (re)exile to the American professorship]. Revista Pedagógica, 21, 395-412.

Hallin, D.C., \& Papathanassopoulos, S. (2002). Political clientelism and the media: southern Europe and Latin America in perspective. Media, Culture \& Society, 24, 175-195.

Intercept Brasil (2019). As mensagens secretas da Lava Jato [The secret messages of Lava Jato]. https:// theintercept.com/series/mensagens-lava-jato/. Accessed 22 Dec 2019.

International Commission for the Study of Communication Problems, MacBride, Sean (2004). Many voices, one world: towards a new, more just, and more efficient world information and communication order. Lanham: Rowman \& Littlefield Publishers.

Jacks, N., \& Schmitz, D. (2019). Teorias latino-americanas e os estudos de recepção e consumo midiático brasileiros [Latin American theories and Brazilian media reception and consumption studies]. Chasqui-Revista Latinoamericana de Comunicación, 141, 177-192.

Jobim, D. (1954). French and US influences upon the Latin American press. Journalism Quarterly, 31, 61-66.

Josephi, B. (2017). Mapping communication and journalism studies in Australia. Publizistik, 62, 465-478.

Kunsch, M., \& Gobbi, M.C. (2016). O campo acadêmico-científico da comunicação no Brasil: panorama, constituição e perspectivas [The academic-scientific field of communication in Brazil: panorama, constitution and perspectives]. Anuario Estudios En Comunicación Social Disertaciones, 9, 68-91.

Lage, N. (2002). À frente, o passado [Ahead, the past. In Federação Nacional de Jornalistas (Ed.), Formação superior em jornalismo: uma exigência que interessa à sociedade [Higher education in journalism: a requirement that interests society] (pp. 57-72). Florianópolis: Imprensa da UFSC. 
Lins da Silva, C.E. (1991). O adiantado da hora: a influência americana sobre o jornalismo brasileiro [The advance of the hour: the American influence on Brazilian journalism]. São Paulo: Summus Editorial.

Löffelholz, M., \& Rothenberger, L. (2011). Eclectic continuum, distinct discipline or sub-domain of communication studies? Theoretical considerations and empirical findings on the disciplinarity, multidisciplinarity, and transdisciplinarity of journalism studies. Brazilian Journalism Research, 7(1), 7-29.

Machado, E. (2005). From journalism studies to journalism theories. Three assumptions to consolidate journalism as a field of knowledge. Brazilian Journalism Research, 1(1), 11-23.

Maxwell, K. (2000). Por que o Brasil foi diferente? O contexto da independência [Why was Brazil different? The context of independence]. In C.G. Mota (Ed.), Viagem incompleta. A experiência brasileira 1500-2000 [Incomplete journey. The Brazilian experience 1500-2000] (pp. 177-196). São Paulo: Editora SENAC.

Mede, N.G., \& Schäfer, M.S. (2020). Science-related populism: conceptualizing populist demands toward science. Public Understanding of Science, 29, 473-491.

Merkley, E. (2020). Anti-intellectualism, populism, and motivated resistance against expert consensus. Public Opinion Quarterly, 84, 24-48.

Meyer, E. (2018). Judges and courts destabilizing constitutionalism: the Brazilian judiciary branch's political and authoritarian character. German Law Journal, 19, 727-768.

Motta, R.P.S. (2014). As universidades e o regime militar [The universities and the military regime]. Rio de Janeiro: Zahar.

Oliveira, T., Holbach, A., Grohmann, R., \& Tavares, C. Q. (2020). E se os editores de revistas científicas parassem? A precarização do trabalho acadêmico para além da pandemia [What if the publishers of scientific journals stopped? The precariousness of academic work beyond the pandemic]. Revista Contracampo, 39(2), 1-14.

Recuero, R. (2015). GT de Cibercultura da Compós: análise de temas e coautorias GT of cyberculture of composites: analysis of themes and co-authorships. Intexto, 34, 553-570.

Saucedo Añez, P.C. (2019). Die lateinamerikanische Medien- und Kommunikationswissenschaft zwischen ideologischer Prägung und begrenzter Internationalisierung: Zeit für Selbstkritik [Latin American media and communication studies between ideological influence and limited internationalization: Time for self-criticism]. Global Media Journal-German Edition, 9(2), 1-16.

Tota, A.P. (2009). The seduction of Brazil: the americanization of Brazil during world war II. Austin: University of Texas Press.

Zelizer, B. (2004). Taking journalism seriously. News and the academy. Thousand Oaks: Sage.

Prof. Dr. A. de Albuquerque is a professor in Communication Graduate Program at Fluminense Federal University.

Prof. Dr. C. Q. Tavares is a professor in Communication Graduate Program at Maranhão Federal University. 